\title{
РЕЦЕНЗIї. ХРОНІКА
}

УДК 811.161 .2

А. А. Ковтун

\section{НОВІ НАПРАЦЮВАННЯ У СФЕРІ ВІТЧИЗНЯНОЇ ТЕОЛІНГВІСТИКИ}

(Піддубна Н. В. Теорія теолінгвістики: феномен біблійності в українській лінгвокультурі та омовлення релігійної картини світу (аналіз дискурсивної практики XIX ст.): монографія. Харків: Майдан, 2019. 448 с.)

Монографічне дослідження Н. В. Піддубної присвячене актуальній для українського мовознавства проблемі становлення й розвитку теолінгвістики - нового для сучасного мовознавства наукового напряму, що грунтується на міждисциплінарному підході, адже актуалізує не лише лінгвістичну парадигму, але й знання у сфері релігії. Вивчення ресурсів, за допомогою яких мовці здавна намагаються пояснити різні культурні феномени, є однією з тем «зовнішньої» лінгвістики: «Мова і суспільство», «Мова і свідомість», «Мова і культура», «Мова і релігія» та ін. Саме зв'язок «Мова і релігія», на відміну від «Релігія та мистецтво», «Релігія та право» чи «Релігія та школа», має найдовшу історію, тісно пов'язану з неусвідомленими механізмами людської психології та культури.

Дослідження виконано з урахуванням таких напрямів мовознавства, як соціолінгвістика, лінгвокогнітологія, лінгвокультурологія, лінгвістика его-тексту, лінгвоаксіологія та ін.

Робота має чітку й умотивовану структуру: складається з переднього слова, підготованого проф. Т. А. Космедою, списку прийнятих скорочень, передмови, чотирьох розділів, висновків, 13 додатків, списків використаної літератури та ілюстративних джерел, покажчика імен.

У Передньому слові професор Т. А. Космеда схарактеризувала внесок Наталії Віталіївни в становлення власне української теолінгвістики, стисло вказавши на науковий поступ дослідниці, іiі досягнення, новаторство, теоретичне значення монографії, зауваживши, що Н. В. Піддубна належить до вітчизняної наукової еліти з великим креативним потенціалом. 
У Передмові мотивовано актуальність, новизну, сформульовано мету та завдання дослідження, повідомлено про методологічну основу праці - усе те, чого потребує цей фрагмент жанру наукової монографіï.

У першому розділі «Теолінгвістика як самостійний науковий напрям: його теоретичні засади. Історія української теолінгвістики» дослідниця вказує на соціолінгвістичне й лінгвокультурологічне походження терміна теолінгвістика, яким нині послуговуються вчені Англії, Бельгії, Польщі, Росії, Сербії, Словаччини, України, і переконує в доцільності актуалізувати його у вітчизняному мовознавстві. Приставши до цього терміна, Н. Піддубна чітко окреслює власне розуміння теолінгвістичного об'єкта - його багатовекторність, комплексну аспектність взаємодії релігії та мови, фіксації релігійної свідомості в мовній картині світу (Піддубна, 2019: 35), а не лише вузьку релігійну сферу, релігійну комунікацію. Така позиція нам імпонує, тому що ми також вважаємо теолінгвістику, яка виникла на стику мови й релігії, наукою надрелігійною, надконфесійною, покликаною досліджувати релігійні вияви, закріплені й відображеній не лише в релігійній, а й у позарелігійній сфері.

Авторка переконує, що теолінгвістика має свій предмет, об'єкт, історію, методологічну базу, відповідне термінополе, яке докладно характеризує з урахуванням проблемних питань. Н. В. Піддубна обирає загальну назву предмета вивчення теолінгвістики - теонема, спираючись на праці О. К. Гадомського, І. В. Бугайової, К. Кончаревич, подаючи при цьому визначення О. Гадомського: теонема - це «мовна одиниця теологічного змісту, що може бути репрезентована у вигляді синтаксичних, фразеологічних, лексичних, словотворчих, морфологічних, морфонологічних, фонологічних варіантів на відповідних ярусах мовної системи» (Піддубна, 2019: 29). В авторській дефініції робочого терміна теонема, що є гіперонімом до бібліїзм («Теонема - це відповідний семантичний чи конотативний (прагматичний) iнваріант, що має здатність зреалізовуватися на кожному рівні мовної системи» (Піддубна, 2019: 376)), доречно було б, на нашу думку, уточнити, які одиниці дослідниця вважає теонемними (пов'язані лише з поняттям «Бог» чи всі релігійні поняття в релевантній концептосфері); одразу, на перших сторінках монографії, указати на теонемні різновиди - це зняло б питання, чому надано перевагу термінові теонема, а не звичному теонім. 
У теоретичному розділі розлого описано етапи становлення української теолінгвістики, що свідчить про велику обізнаність дослідниці з багатьма вітчизняними напрацюваннями і широкою традицією слов'янського мовознавства. Н. В. Піддубна аналітично осмислює здобутки мовознавчої науки та суміжних дисциплін, у центрі яких глобальна проблема «Мова і релігія». Особливо скрупульозно дослідниця упрозорює національний розвиток теолінгвістичної теорії й практики, що грунтується на ретельному вивченні й систематизації праць українських лінгвістів різних періодів: від О. О. Потебні, I. I. Огієнка, О. Т. Горбача, Л. А. Булаховського та ін. до В. В. Німчука, О. К. Гадомського та ін. Н. В. Піддубна звертає увагу на роботу «Історія української мови: Лексика і фразеологія» за ред. В. М. Русанівського, у якій задекларовано одне із завдань теолінгвістики, що виводить ії за межі релігійного дискурсу, - «простежити особливості функціювання та переосмислення релігійної лексики й фразеології в художньо-публіцистичному мовленні, вияв стилістичного чи - ширше - прагматичного їхнього навантаження» (Піддубна, 2019: 54). Особливо захоплено автор рецензованої праці аналізує спадщину академіка АН УРСРЛ. А. Булаховського, завершуючи висновком: «Можемо однозначно стверджувати, що Л. Булаховський стояв біля початків української теолінгвістики, що на той час лише зароджувалася» (Піддубна, 2019: 58). Таку думку, на наше переконання, варто ще обговорювати, оскільки цю місію у ХX ст. блискуче виконував I. I. Огієнко - український мовознавець, лексикограф, історик церкви, єпископ, митрополит УАПЦ, предстоятель УГПЦК, політичний, громадський і церковний діяч, який через свою патріотичну позицію вимушений був покинути Батьківщину. Спадщину I. Огієнка дослідниця стисло окреслює, описуючи його етимологічні напрацювання щодо релігійної лексики й те, що «значну частину наукового доробку I. Огієнка становлять праці з історії мови та церковнослов'янської мови», згадує його погляди на проблеми перекладу Святого Письма українською мовою (Піддубна, 2019: 45). Проте додамо й про несказане: I. Огієнко не зупинився на теоретичному опрацюванні положень проблеми взаємозв'язку релігійного й мовного чинників, про які у своїх працях писав Л. Булаховський. І. Огієнко не лише висунув концепцію мови як духовного ареалу народу, а й практично й утілив iii частково, створивши один із найкращих перекладів Священного 
Письма - основу для розвитку свої великої ідеї - здійснення церковних богослужінь рідною мовою.

Здійснений у першому розділі аналіз термінів сакрум, сакральний, сакралізація, священний, святий, пробанум, профанний, профанізація, секулярний, десакралізація (системна десакралізація та власне десакралізація), ресакралізація (пряма та сполучена) указує на належну поінформованість Н. Піддубної щодо намагання лінгвістів розрізняти ці терміни у своїх наукових теолінгвістичних студіях (хотілося 6 знати думку дослідниці і про терміни осакралення, осакралений, осакралювати, розсакралення, розсакралений, осакралювати, які ми використовуємо у своїх працях). Мовознавиця схиляється до думки Т. Вільчинської «стосовно розуміння сакрального як аксіологічно амбівалентного, що містить на своїх полярних полюсах не лише святе й чисте, а й нечисте, демонічне», і погоджується із співвідносністю сакральної сфери із широкою сферою спілкування на різних рівнях суспільного дискурсу, що «дає мовцям великі виражальні можливості - смислові, прагматичні й експресивні» (Піддубна, 2019: 82).

У другому розділі «Ключові поняття теолінгвістики: релігійний стиль, релігійний дискурс, релігійний текст, релігійна мова, релігіолект» 3'ясовано ключові поняття теолінгвістики. Н. Піддубна констатує проблему виокремлення релігійного стилю, аргументує власну періодизацію розвитку релігійного стилю, деталізує останній етап, з 90-х рр. ХХ ст., описуючи прикметні ознаки різновидів релігійних текстів, підкріплюючи їх власними прикладами, називає підстилі релігійного стилю, за класифікацією Н. Бабич, подає жанрову диференціацію релігійного мовлення, яку здійснили іноземні дослідники, a на їх основі - О. Гадомський (додамо, що у вітчизняному доробку на цю тему $є$ й інші грунтовні праці, наприклад українського теолога й філолога О. Мирончука «Виокремлення підстилів та жанріву конфесійному стилі української мови», 2010 р.). Від аналізу релігійного стилю Н. Піддубна цілком логічно переходить до потрактувань релігійного дискурсу, релігійного тексту, релігійної мови, покликаючись на напрацювання здебільшого російських лінгвістів (для розуміння різниці між дискурсом і текстом тут важливо було чіткіше розставити акценти, адже в назві монографії задекларовано розгляд «дискурсивної практики», а дискурс, як зауважує сама дослідниця на с. 136, корелює з текстом). 
У третьому розділі «Бібліїзм - класифікаційний підтип теонеми, його багатоаспектний статус, системні зв'язки й проблема лексикографування» докладно описано проблему термінологічної дефініції бібліїзу, типи його формально-семантичної структури, термінологічну синонімію, орфографічну варіантність та запропоновано власне визначення бібліїзму (Піддубна, 2019: 170). Н. В. Піддубна цілком слушно звертає увагу на термінологічну омонімію, спричинену іншомовним міжнародним компонентом бібліо-, щоб застерегти від вживання терміна бібліонім для позначення антропоніма чи топоніма, ужитого в Біблії, оскільки термін бібліонім уже кодифікований у науковій сфері та бібліотечній справі; при цьому авторка дає корисні поради щодо використання й таких спільнокореневих слів, як біблієонім, біблієма, біблема (Піддубна, 2019: 193-196). Зауваживши, що термін біблійна лексема є синонімійним до терміна лексичний біблї̈зм, дослідниця в цьому ж розділі розглядає гіперо-гіпонімійні зв’язки між поняттями «релігійна лексика / фразеологія» і «біблійна лексика / фразеологія», а також «прецедентний релігійний феномен» і «прецедентний біблійний феномен».

У підрозділі, присвяченому дериваційним, стильовим і стилістичним можливостям бібліїзмів, сконденсовано напрацювання багатьох мовознавців, думки яких підтверджені різностильовим фактичним матеріалом релігійного та світського характеру, що доводить потужний семантико-стилістичний потенціал фразеологізмів біблійного походження (оновлення поза релігійним мовленням функцій бібліїзмів-антропонімів, бібліїзмів-топонімів та ін., залучення їх до заголовків, що супроводжується «вивільненням» певних семантичних компонентів зі складу фразеологізмів унаслідок стискування стійких словесних комплексів, тощо).

В огляді статусу бібліїзму як прецендентної одиниці української мови Н. В. Піддубна спирається на принципи класифікації прецедентних феноменів, запропонованої російськими дослідниками Д. Б. Гудковим і В. В. Красних, а класифікацію прецедентних релігійних імен А. А. Берестової вважає цілком придатною для проєкції на прецедентні бібліїзми. Називає типи бібліїзмів за традиційним семантичним і частиномовним критерієм, за походженням (уподобано «діахронічну класифікацію» російської дослідниці К. М. Дубровіної), за критерієм еквівалентності / безеквівалентності (міжмовні еквіваленти подано з позиції російського мовознавця А. П. Василенка). 
Н. В. Піддубна моделює власну польову структуру бібліїзмів (з ядерною, першою і другою приядерною зонами, ближньою та дальньою периферіями), цікавими прикладами характеризує системно-структурні (полісемійні, омонімійні, синонімійні, антонімійні, гіперо-гіпонімійні) та дериваційні зв’язки бібліїзмів, доводячи, «що процеси і семантичної, і словотвірної (лексичної) деривації бібліїзмів продуктивні» (Піддубна, 2019: 234). Порушено й питання джерел проникнення бібліїзмів в українську мову, причин їх трансформації, лексикографічної інтерпретації лексико-фразеологічних бібліїзмів української мови.

Для виявлення особливостей омовлення релігійної картини світу, віддзеркалення концептів, що є складниками релігійної концептосфери, у четвертому розділі «Вербалізація релігійного складника в дискурсі (на прикладі аспектного аналізу мовотворчості Т. Шевченка і С. Руданського)» Н. В. Піддубна обирає двох українських письменників. У попередніх заувагах дослідниця аргументує свій вибір малодослідженістю епістолярію та щоденників Т. Г. Шевченка, низкою суперечливих питань щодо ставлення Кобзаря до Бога й віри, а також перебуванням на маргінесі наукових досліджень листування С. В. Руданського (сина священника) і неправдивим потрактуванням його художньої спадщини, що так само засноване на постулюванні радянської антирелігійної й антинаціональної ідеології.

Дослідниця звертається до підбірки оцінок науковців, які констатують антишевченківське переосмислення Бога, що «перевернуло призму Шевченкового світосприймання і здрібнило великі світила Шевченкового світу - Любов, Істину, Волю, Добро, Матір, Україну...» (Є. Сверстюк); аналізує стан вивчення проблеми вербалізації релігійного світогляду Т. Г. Шевченка в його еgо-текстах, наголошуючи на подоланні Кобзарем схильності до стилізації листів під «мужичу» мову, відхід від «котляревщини», унаслідок чого українську епістолярію Кобзаря, за твердженням В. М. Русанівського, можна вважати зародком українськомовної публіцистики (Піддубна, 2019: 274).

Аналізуючи семантичні трансформації релігійної лексики в щоденнику Т. Г. Шевченка, мовознавиця виокремлює в них 11 лексикосемантичних груп, звертає увагу й на «екзотичні» релігійні лексеми (намаз, Немезида та ін.), які інтелектуалізують мовлення, доводить збагачення лексичного фонду мови семантикою релігійних слів, 
розширеною з появою переносних значень (інквізиція, жрець, апостол та ін.).

За спостереженнями Н. Піддубної, сприйняття Бога у листах Т. Шевченка винятково позитивне, на відміну від амбівалентного сприйняття Бога в художніх текстах (Піддубна, 2019: 283). Більшість релігійних лексем $є$ прецедентними, глибоко символічними, що виявляється не в кількісному використанні релігійної лексики, а в сприйнятті Господа, експлікованому такими найважливішими релігійними концептами, як: БОГ, ВІРА, БІБЛІЯ, ХРИСТИЯНСТВО, МОЛИТВА, ХРАМ, СВЯЩЕННОСЛУЖИТЕЛЬ. Дослідниця зупиняється на кожному з них в окремих підрозділах монографії, виокремлюючи актуалізацію смислів: для БОГ - 'терпіння', 'страждання', 'милосердя', 'довершеність', 'людинолюбство'; для ВIPA - 'остання надія', 'вищий вияв надії і т. д. Звертає увагу на значення молитви як інтимної розмови з Господом у житті Кобзаря, на схиляння перед Богом, вірою, Біблією і на критичне ставлення Т. Шевченка до священників різних рангів, російського православ'я як одного із засобів механізму царської внутрішньої політики, зокрема підкорення народів Російської імперії, до надмірності завантаження різними предметами й архітектурними елементами російських церков, що нагадували йому буддійські храми.

Достатньо широко проаналізовано в цьому розділі ще одну з характерних ознак еgо-текстів Т. Г. Шевченка - біблійність. Прецедентні агіоніми, демоніми (орконіми), ангелоніми, міфотопоніми, клерикалоніми, геортоніми, вирази (прямі й непрямі), біблійні алюзії, бібліїзми, «замішані» на фольклорі та біблійні тексти стали невід'ємними складникам портретування й автопортретування глибокої релігійності великого письменника-інтелектуала. До таких висновків підводить і аналіз використання мовноетикетних формул як сакральних етноментальних особливостей українців, відображених у мовленні Кобзаря.

Етикетні мовленнєві формули зі складниками-теонімами й фразеологізовані вислови з демононімами Н. В. Піддубна описує й у листах С. В. Руданського, що репрезентують прагнення максимально інтимізувати епістолярне спілкування, традицію викривання людських вад незалежно від соціального статусу, а також відображають типові лексичні компоненти живого українського мовлення. 
У поетичному мовленні С. В. Руданського мовознавиця з'ясовує своєрідність омовлення образу-концепту БОГ через прецедентні релігійні одиниці таких груп: храмів різних релігійних конфесій та їх частин, релігійних таїнств та обрядів, біблійних антропонімів, біблійних демононімів, релігійних агіонімів (християнонімів), депрекатіонімів (християнських молитов).

Н. В. Піддубна витлумачує жартівливе ставлення С. В. Руданського до Бога (іноді), приземлення, інтимізацію образу Всевишнього амбівалентним ставленням до християнських святинь у народному середовищі, що сприймаються і як сакральні, і як потенційно смішні. Крім цього, як стверджує авторка, на С. В. Руданського також мали вплив різноманітні народні анекдоти, базовані на бурлескних різдвяних і великодніх віршах, що їх у XIX ст. збирав з народних уст і систематизував письменник. Дослідниця спрямовує до низки творів письменника, досі не належного висвітлених, - надзвичайно цінних поетичних коментарів до вічних перлин християнства, свідчень того, що обробка Святого Письма українською мовою, безперечно, була для письменника першочерговим завданням. Образ-концепт СВЯЩЕННОСЛУЖИТЕЛЬ, вербалізований низкою лексем, С. В. Руданський нерідко виносив навіть у заголовки своїх віршів з гумористичною тональністю, що Н. Піддубна пояснює як висміювання людських вад узагалі, а не вад священників, із кого письменник кпинить найдошкульніше, оскільки саме вони повинні бути зразком в усьому.

Виклад кожного розділу та підрозділу рецензованої монографії відзначається максимальною коректністю, логічними зв'язками, супроводжується чіткими висновками; текст цікавий, читабельний, композиційно довершений. Дослідження є багатоплановим і щодо перспективи застосування результатів, оскільки має виразне прикладне спрямування: крім лексико-семантичного рівня та фразеологічного підрівня, $є$ потреба докладно описати й специфіку вербалізації чи граматикалізації теонем, удосконалити лексикографічні аспекти репрезентації сакральної сфери, доповнити релігійну мовну картину світу українців.

Попри високу оцінку рівня наукового викладу та новизни результатів дослідження Н. В. Піддубної, маємо деякі свої міркування. Хотілося б, щоб авторка більше спиралася на багату спадщину українських, а не російських мовознавців (без уваги залишилася, 
наприклад, грунтовна праця Л. Скрипник «Фразеології української мови» (1973), у якій, окрім особливостей семантики й форми фразеологізмів, джерел виникнення, еволюційних процесів у фразеологічному фонді української мови, схарактеризовано й крилаті вислови релігійного характеру, витлумачено бібліїзми; не скористалася авторка й новішими вітчизняними напрацювання, наприклад «Нарисами з української фразеології: психокогнітивний та етнокультурний аспекти» (2004) О. Селіванової; не залучено трактувань зі словника-довідника фразем біблійного походження «Слово Благодаті» Ж. Колоїз та 3. Бакум, у якому, на відміну від цитованих у монографії лексикографічних джерел, досить глибоко роз'яснено конкретні умови виникнення біблійних фразем, їх вихідну семантику).

У теоретичних розділах варто сміливіше пропонувати власні дефініції термінів, що визначають метамову рецензованої роботи; поряд із зібраними й ретельно описаними поглядами мовознавців на ту чи ту проблему, можна було чіткіше декларувати авторську позицію, вказувати на нові елементи в класифікаціях тощо.

У додатках помічною була 6 візуалізація різновидів теонем й аналізованих мовних одиниць (їх кількісних показників зокрема) у мовотворчості Т. Г. Шевченка й С. В. Руданського. Назви й цитати з іноземних праць бажано все-таки перекладати українською мовою.

Висловлені міркування аж ніяк не применшують загальнотеоретичної й практичної вартості рецензованої праці та приємного враження від прочитаного. Безперечно, монографія Наталії Віталіївни Піддубної «Теорія теолінгвістики: феномен біблійності в українській лінгвокультурі та омовлення релігійної картини світу (аналіз дискурсивної практики XIX ст.)» займе достойне місце в українському мовознавстві.

Ковтун Альбіна Анатоліївна - доктор філологічних наук, доцент, доцент кафедри історії та культури української мови, Чернівецький національний університет імені Юрія Федьковича, Україна, м. Чернівці, вул. Коцюбинського, 2.

Тел.: +38-095-380-73-33

E-mail: albkovtun500@gmail.com

http://orcid.org/0000-0002-0690-3265

Kovtun Albina Anatoliivna - Doctor of Philology, Associate Professor, Department of History and Culture of the Ukrainian Language, Chernivtsi National University named after Yuri Fedkovych, Ukraine, Chernivtsi, vul. M. Kotsiubynskyi, 2.

Надійшла до редакції 25 жовтня 2019 року 